\title{
Source Term Estimation and the Isotopic Ratio of Radioactive Material Released from the WIPP Repository in New Mexico, USA.
}

\author{
P. Thakur \\ Carlsbad Environmental Monitoring \& Research Center, 1400 University Drive, Carlsbad, New \\ Mexico-88220, USA.
}

\begin{abstract}
After almost 15 years of operations, the Waste Isolation Pilot Plant (WIPP) had one of its waste drums breach underground as a result of a runaway chemical reaction in the waste it contained. This incident occurred on February 14, 2014. Moderate levels of radioactivity were released into the underground air. A small portion of the contaminated underground air also escaped to the surface through the ventilation system and was detected approximately $1 \mathrm{~km}$ away from the facility. According to the source term estimation, the actual amount of radioactivity released from the WIPP site was less than 1.5 millicurie. The highest activity detected on the surface was $115.2 \mu \mathrm{Bq} / \mathrm{m}^{3}$ for ${ }^{241} \mathrm{Am}$ and $10.2 \mu \mathrm{Bq} / \mathrm{m}^{3}$ for ${ }^{239+240} \mathrm{Pu}$ at a sampling station located 91 meters away from the underground air exhaust point and 81.4 $\mu \mathrm{Bq} / \mathrm{m}^{3}$ of ${ }^{241} \mathrm{Am}$ and $5.8 \mu \mathrm{Bq} / \mathrm{m}^{3}$ of ${ }^{239+240} \mathrm{Pu}$ at a monitoring station located approximately one kilometer northwest of the WIPP facility. The dominant radionuclides released were americium and plutonium, in a ratio that matches the content of the breached drum.

Air monitoring across the WIPP site intensified following the first reports of radiation detection underground to determine the extent of impact to WIPP personnel, the public, and the environment. In this paper, the early stage monitoring data collected by an independent monitoring program conducted by the Carlsbad Environmental Monitoring \& Research Center (CEMRC) and an oversight monitoring program conducted by the WIPP's management and operating contractor, the Nuclear Waste Partnership (NWP) LLC were utilized to estimate the actual amount of radioactivity released from the WIPP underground. The Am and Pu isotope ratios were measured and used to support the hypothesis that the release came from one drum identified as having breached that represents a specific waste stream with this radionuclide ratio in its inventory. This failed drum underwent a heat and gas producing reaction that overpowered its vent and lifted its lid to allow release of waste into the underground air.
\end{abstract}




\section{Introduction}

The U.S. Department of Energy's (DOE's) Waste Isolation Pilot Plant (WIPP) is the nation's only deep geologic repository for the permanent disposal of transuranic, or TRU waste generated primarily from the research and production of nuclear weapons. Located in the Chihuahuan desert of southeastern New Mexico near Carlsbad, the WIPP repository is mined within a 600 meter-thick bedded-salt formation. The underground part of WIPP is located $655 \mathrm{~m}$ below the surface of the Earth. The TRU waste, which typically consists of clothing, tools, rags, residues, debris, soil and other items contaminated with small amounts of plutonium and other man-made radioactive elements is sealed in 208 liter drums, as well as larger containers, and transported to the WIPP from various generator sites for permanent disposal. The WIPP become operational in March 1999, and has since disposed of more than 86,000 cubic meters of TRU waste in more than 165,000 containers. Over its lifetime, WIPP is expected to dispose of approximately 175,000 cubic meters of TRU waste from various DOE sites. The WIPP is about half full in terms of its legally defined capacity. The radionuclides of greatest concern in the WIPP are ${ }^{239+240} \mathrm{Pu}$, and ${ }^{241} \mathrm{Am}$, which account for more than $99 \%$ of the total radioactivity scheduled for disposal in the repository.

As shown in Figure 1, the WIPP repository layout currently has eight panels planned, each consisting of seven waste disposal rooms approximately 91 meters long and 10 meters wide. Seven of the panels have been excavated; and the first six have been closed and sealed from ventilation air. Panel 7 is the current active waste disposal area. Its Room 7 is where the release event occurred. Room 7 of Panel 7 was closed shortly after the accident investigation concluded to seal it off from underground air circulation.

There are four shafts that connect the surface with the underground. The air intake and exhaust shafts provide the necessary air circulation for the underground. The air intake shaft provides the greatest percentage of air to the underground. The salt handling shaft is used to remove mined salt from the underground and also serves as an air intake shaft. The waste handling shaft is used to transport TRU waste containers to the underground for emplacement. The waste and the salt shafts are also the primary means for transport of personnel and equipment to and from the underground. The facility also consists of common drifts for access and ventilation to the disposal panels and above ground waste receipt and handling facilities. 
Normally the underground area of the repository is strongly ventilated by drawing outside air through the air intake shaft and then exhausting it out to the environment through the exhaust shaft using exhaust fans located on the surface. Continuous Air Monitors (CAMs) underground are used to control whether or not the ventilation returning to the surface is passed through these large filter systems before it is released to the atmosphere. When the air monitors sense any contamination, the ventilation system is automatically switched to the filtration mode allowing the exhaust air stream to pass through a pair of large HEPA (High Efficiency Particulate Air) filter systems, before being put back into the environment. WIPP has been in "filtration mode" since the events of February 2014.

\section{February 14, 2014, Radiation Release Event at WIPP}

On Friday, February 14 at 11:13 pm MST (Mountain Standard. Time), a CAM-151 detected a radiological release in the underground. The CAM-151 was located immediately downstream and outside of Panel 7 where waste was being emplaced. The Waste emplacement operations had been suspended nine days earlier because of the February 5, 2014 fire incident (DOE 2 2014a). As soon as the CAM alarmed on the night of February 14, the WIPP's ventilation system automatically switched to the filtration mode, reduced the air flow, and directed the exhaust air stream through the filter banks when it reached the surface. This automated actuation of filtration mode is intended to protect aboveground workers at the site and the public in the surrounding areas by minimizing radiation releases to the environment in the event of an accident involving waste underground. The ventilation system appeared, at the time, to be functioning as designed, so there was no reason to suspect any substantial release to the environment.

A small portion of the contaminated air bypassed the HEPA filters via leakage through two imperfectly sealing ventilation system dampers and was discharged directly to the environment from an exhaust duct. The actual release into the atmosphere, based on on-site and near off-site monitors was very small, localized, and below any level of public-health or environmental concern. The dampers have since been sealed off with high-density expanding foam insulation. Since this incident occurred during the night, only a few employees were at the WIPP site and no employees were in the underground. However, twenty-one individuals were identified through bioassay to have incurred very low-level amounts of internal contamination as 
a result of the release after they came onsite the following day. All follow-up tests were below the detectable limits of the laboratory analysis indicating no long-term adverse health effects are expected for these employees.

Soon after the radiation release events, the Department of Energy- Office of Environmental Management (DOE-EM) appointed an Accident Investigation Board (AIB) to determine the cause of the radiation release and to develop recommendations for corrective actions. The AIB released its findings in two phases. The Phase-1 report included initial investigations of the atmospheric release from the WIPP underground and related exposure to workers aboveground, as well as the operational and emergency response to the radioactive release. The results were published on April 24, 2014 (DOE, 2014b). The Phase-2 report (DOE, 2015a) examined the cause of the 2014 radiological release event at WIPP. Based on post-event chemical, radiological, and fire forensic investigations, the report concluded that the release was caused by a runaway chemical reaction inside a TRU drum (drum \# 68660). This drum contained nitrate salt-bearing transuranic TRU waste that originated from Los Alamos National Laboratory. There was no indication of release from any other waste containers.

A Technical Assessment Team (TAT) of experts from US National Laboratories was also set up to perform a comprehensive, independent scientific review of the mechanisms and chemical reactions that may have contributed to the radioactive release (TAT-report, 2015.) The TAT report concluded that one drum, Drum 68660, was the source of radioactive contamination in WIPP. The contents of Drum 68660 were chemically incompatible, and the drum breached as a result of internal chemical reactions.

The isotopic and also the chemical forensics, as discussed in both the Technical Evaluation Team (TAT-Report, 2015) and the Phase II Accident Investigation Board (DOE, 2015a) reports, indicated that one drum had released material as a consequence of the inappropriate use of an organic absorbent and an organic neutralizing agent in a nitrate-salt waste. The organic neutralizer and absorbent constitute fuel for the strongly oxidizing nitrate salts in the drum. The organic absorbent and its oxidation products were found in the matter expelled from the drum, suggesting it was the primary fuel. The Accident Investigation Board found several process errors contributed to this occurrence. The primary one being that the organization in charge of waste processing: "Did not ensure appropriate SME (subject matter expert) involvement and/or technical evaluation of specification of change to an organic 
absorbent. In addition, changes to neutralizers also were not sufficiently controlled." The procedure was confusing, specifying "an organic" absorbent, and at the same time giving "zeolite" as an example, an inorganic clay that would not have reacted with the nitrate salts.

Air monitoring across the WIPP site intensified following the first reports of radiation detection underground to determine the extent of impact to WIPP personnel, the public, and the environment. In this paper, the early stage monitoring data collected by an independent monitoring program conducted by the Carlsbad Environmental Monitoring \& Research Center (CEMRC) and an oversight monitoring program conducted by the WIPP's management and operating contractor, the Nuclear Waste Partnership (NWP) LLC were utilized to estimate the actual amount of radioactivity released from the WIPP underground. The ${ }^{238} \mathrm{Pu} /{ }^{239+240} \mathrm{Pu}$, ${ }^{241} \mathrm{Pu} /{ }^{239+240} \mathrm{Pu},{ }^{241} \mathrm{Am} /{ }^{239+240} \mathrm{Pu}$ and ${ }^{241} \mathrm{Am} /{ }^{243} \mathrm{Am}$, and ${ }^{240} \mathrm{Pu} /{ }^{239} \mathrm{Pu}$ atom ratios were utilized to characterize the isotopic signature of the material released from the WIPP underground.

\section{Experimental}

\section{Underground Air Samples Collection}

Underground air samples were collected from Station A and Station B. Station A samples the unfiltered underground exhaust air. Station B samples the underground exhaust air after HEPA filtration and, sometimes, non-filtered air during maintenance. Station A and Station B were sampled every 8 hours, respectively, after the release event and measurements were performed on each individual filter for some time following the radiation release event. As airborne concentrations receded, the exhaust air samples were collected daily (24 hour samples) from Station A and Station B, and composited daily for analysis. Each station is a fixed air sampler, collecting particulates from the underground air on a Versapor filter $(3.0-\mu \mathrm{m}$ pore size and 47-mm diameter, PALL Corporation).

The samplers at Station A are three nearly identical shrouded-probes that can accurately sample the air stream and its aerosol particles under a wide range of flow conditions and particle sizes. The air from three aerosol sampling probes flows through separate lines into the Station A enclosure where the air in each line is distributed among three sampling legs. Thus, a total of three concurrent samples can be collected from Station A, one each for CEMRC, the WIPP site contractor (Nuclear waste Partnership, LLC, NWP), and the New Mexico Environment Department (NMED). The design and testing of the shrouded probes confirmed that this 
configuration allows collection of representative air samples (Gross et al., 2011). Under normal operating conditions at WIPP prior to the release event, the exhaust air was not filtered. Since the radiological incident on February 14, 2014, the WIPP ventilation system remains in filtration mode.

Under normal (non-filtration) operating conditions, each day approximately $81 \mathrm{~m}^{3}$ (cubic meter) of air was filtered through the Versapor filter at Station A. Prior to the radiation release event, the samples at Station A were collected daily except for weekends (the weekend samples run from Friday to Monday so the coverage is continuous). However, occasionally more than one sample per day was collected if the flow rate on any of the sampler legs dropped below $0.06 \mathrm{~m}^{3}$. When this occurred, a low-flow alarm on the sampler was activated and the filters were changed.

Weekly filter (24 hours/seven days per week) samples were typically collected at Station B. Each week at Station B, approximately $583 \mathrm{~m}^{3}$ of air were filtered through the Versapor filter. Prior to the release event filter samples were combined monthly for Station A for analysis by CEMRC and NWP, and quarterly for Station B for analysis by NWP. As airborne concentrations have receded, the exhaust air samples continue to be collected daily ( 24 hour sample) from Station A and Station B, but are composited weekly for analysis.

\section{Ambient Air Samples}

Airborne particulate samples were and are still collected using high volume samplers ("hivols," flow rate $\sim 1.13 \mathrm{~m}^{3} \mathrm{~min}^{-1}$ ). The CEMRC operates a network of continuously operating samplers at three locations in the vicinity of the WIPP site. These monitoring stations are located at: (1) Onsite, which is about $0.1 \mathrm{~km}$ northwest of the WIPP exhaust shaft, (2) Near Field, about $1 \mathrm{~km}$ northwest of the facility; and (3) Cactus Flats, about $19 \mathrm{~km}$ southeast of the WIPP site. These sites were selected based on an analysis of prevailing wind-direction and speed scenarios in case of an accident involving a release of radioactivity during the operation of the WIPP. The aerosol samples were collected on $20 \times 25 \mathrm{~cm} \mathrm{~A} / \mathrm{E}^{\mathrm{TM}}$ glass fiber filters (Pall German Laboratory, Ann Arbor, MI). Under normal operating conditions, these filters were collected over a period of 3 to 6 weeks depending on the levels of particulate matter that accumulated on the filters.

Following the radiation release event, filters are being changed and analyzed weekly.

Additionally, NWP operates seven low- volume air samplers in the WIPP vicinity (DOE, 2012). These monitoring stations are located at Carlsbad (CBD), Smith Ranch (SMR), Mills 
Ranch (MLR), WIPP South (WSS), WIPP East (WEE), WIPP Far Field (WFF), and the Southeast Control sites (SEC) (Figure 2). The Southeast Control site is located approximately 12 miles southeast of WIPP. This air sampling location is in the predominant upwind direction of WIPP.

Weekly filter samples are typically collected at these sampling locations. Each week at each sampling location, approximately $600 \mathrm{~m}^{3}$ of air is sampled through a 47-centimeter $(\mathrm{cm})$ diameter glass microfiber filter. Following the radiation release event, NWP deployed additional air monitors in the WIPP vicinity and accelerated sampling and analysis frequency.

\section{Separation of Individual Actinides}

Filter samples collected were prepared for radiochemical analysis by wet digestion with $\mathrm{HNO}_{3}, \mathrm{HCl}$ and perchloric acid until the filter was totally dissolved. This mixture was heated to dryness and then re-dissolved in $20 \mathrm{~mL}$ of $1 \mathrm{M} \mathrm{HCl}$. Generally, one half of the sample was used for the determination of the actinide activities and other half for gamma analysis. However, for the filters collected immediately after the incident when the potential for high-levels of contaminant was significant, appropriate dilutions of filter solutions were made prior to actinide separations. The actinides were concentrated in an iron hydroxide precipitate as $\mathrm{Fe}(\mathrm{OH})_{3}$. After decantation and centrifugation, the precipitate was dissolved in $10 \mathrm{ml}$ of conc. $\mathrm{HNO}_{3}$ and diluted to $20 \mathrm{ml}$ to make the solution $8 \mathrm{M}$ in $\mathrm{HNO}_{3}$. The oxidation state of plutonium as $\mathrm{Pu}(\mathrm{IV})$ was adjusted by adding $1 \mathrm{ml}$ of $1 \mathrm{M} \mathrm{NH}_{4} \mathrm{I}$ with a $10 \mathrm{~min}$ wait step, followed by $2 \mathrm{ml}$ of $2 \mathrm{M} \mathrm{NaNO}_{2}$. Plutonium was separated from americium and uranium using an anion exchange column (Eichrom 1-×8, 100-200 mesh, chloride form, $15 \mathrm{~mm}$ diameter $\times 10 \mathrm{~cm}$ long) pre-conditioned with $50 \mathrm{ml}$ of $8 \mathrm{M} \mathrm{HNO}_{3}$. Large columns were used to obtain faster flow rates. The fraction containing americium and uranium was separated using a TRU-resin (tri n-butyl phosphate, [TBP]) and N, N-diisobutylcarbamoxylmethylphosphine oxide [CMPO]) extraction chromatography column in $2 \mathrm{M} \mathrm{HNO}_{3}$ as described previously (Thakur, et al., 2011). The individual actinides were then micro-co-precipitated with a Nd-carrier (Hindman, 1983) and counted using alpha spectrometry. 


\section{Determination of Individual Actinides}

An alpha spectroscopy system (Canberra) equipped with 48 Passivated Implanted Planar Silicon (PIPS) detectors connected to an Alpha Apex software system was used for the acquisition, analysis and storage of alpha spectra. The nominal counting efficiency for these detectors is 0.20 . Samples were counted for at least 24 hours. A set of stainless steel alpha standards procured from Canberra was used to establish calibration and counting efficiencies. Typical chemical recoveries, determined through spiking the solutions with known amounts of isotopes of interest, are in the range of $40-90 \%$ for $\mathrm{Pu}$ and of $80-105 \%$ for Am. For a counting

time of $1440 \mathrm{~min}$, the detection limits were $0.0009 \mathrm{~Bq} /$ sample for ${ }^{239+240} \mathrm{Pu}$ and ${ }^{238} \mathrm{Pu}$ and 0.0011 $\mathrm{Bq} /$ sample for ${ }^{241} \mathrm{Am}$ in the air filter samples.

Gamma analyses were done using a low-background, high purity germanium (HPGe) detector. Solid samples for gamma analysis were sealed in a 300-mL paint-can and were counted directly over a coaxial HpGe crystal. For filter samples, one half of the acid digestates of the filter samples were brought to $70 \mathrm{~mL}$ in a Qorpak bottle for gamma analysis. A set of mixed gamma standards procured from Eckert and Ziegler Analytics (GA) was used to establish matrixspecific calibration and counting efficiencies.

\section{Determination of ${ }^{241} \mathrm{Pu}$}

For measuring ${ }^{241} \mathrm{Pu}$, the stainless steel alpha planchet containing $\mathrm{NdF}_{3}$ precipitates were placed in a $50 \mathrm{~mL}$ beaker and wetted with $2 \mathrm{~mL}$ of $2 \mathrm{M} \mathrm{HNO}_{3}-2.5 \% \mathrm{H}_{3} \mathrm{BO}_{3}$ and then with 2-3 $\mathrm{mL}$ of additional $2 \mathrm{M} \mathrm{HNO}_{3}$ to ensure the planchet is completely immersed in the solution. The beaker was heated for about an hour at $80-100^{\circ} \mathrm{C}$. The planchet was then removed from the solution and $3 \mathrm{ml}$ of $\mathrm{HClO}_{4}$ was added to each beaker and heated until complete dryness. The residue was then dissolved in $2 \mathrm{~mL}$ of $1 \mathrm{M} \mathrm{HNO}_{3}$ and transferred into liquid scintillation vials and $20 \mathrm{ml}$ of Ultima Gold ${ }^{\mathrm{TM}}$ cocktail was added to each vial. The ${ }^{241} \mathrm{Pu}$ activity was determined using a low-background liquid scintillation counter (Perkin Elmer) with a counting time of 6 hours.

\section{Origin of Nitrate Waste Stream}

The legacy nitrate salt wastes were generated from plutonium recovery operations at LANL in the nineteen-seventies and -eighties. Nitric acid dissolution operations were conducted 
in order to recover plutonium from scrap and residues, and the use of ion-exchange and oxalate precipitation produced a purified plutonium oxide product that could be further converted into plutonium metal. This recovery process generated evaporator nitrate salt and concentrated liquid waste called "bottom wastes". Following plutonium removal, the chemical residues were evaporated and the evaporator bottoms cooled to produce metal nitrate salts. Nitrate salts derived from ion-exchange effluents were washed with concentrated nitric acid, air dried, and packaged for storage. Nitrate salts derived from oxalate precipitation effluents also contained oxalate salts and were washed with water prior to air drying and packaging for storage. In addition to $\mathrm{Am}, \mathrm{Pu}$, $\mathrm{U}$ and minor amounts of other radionuclides, the waste is also expected to contain heavy metals such as cadmium, chromium, and lead and various metal-nitrate salts (strong oxidizers), such as $(\mathrm{Mg}, \mathrm{Ca})\left(\mathrm{NO}_{3}\right)_{2}$ with minor amounts of $\mathrm{Fe}, \mathrm{Na}$ and $\mathrm{K}$ (TAT-Report, 2015).

\section{Content of the Breached Drum}

The nitrate salt waste that was repackaged into drum 68660 was a portion of parent drum S855793. Parent drum S855793 was generated in October 1985 and reportedly contained 14 bags of nitrate salts, four of which resulted from an oxalate precipitation process. The waste still had some liquid nitric acid. WIPP cannot take liquid wastes. So, during repackaging operations an organic kitty litter (Swheat Scoop $®$ ) was used to absorb free liquids and triethanolamine (TEA) was used as a neutralizing agent. A tungsten lined glovebox glove was added to drum 68660 as a secondary waste. Some other secondary waste generated during remediation and repackaging operations such as Fantastik ${ }^{\circledR}$ bottles used during decontamination, miscellaneous hand tools, paper/plastic tags and labels, plastic/metal wire ties, personal protective equipment, plastic sheeting used for contamination control, rags and wipes (Kimwipes) were also put into the drum. The Technical Assessment Team that investigated the cause of the drum breach deemed that the Swheat Scoop brand litter used by LANL was chemically incompatible with the contents of the drum. The organic ingredients reacted with the waste and created gases that increased the pressure in the drum. The materials self-heated and combusted. The combination of the nitrate salt residues, organic sorbent (Swheat Scoop ${ }^{\circledR}$ ), and neutralizing agent (TEA) represent a reactive chemical mixture of fuels and oxidizers.

The detailed chemical composition of the nitrate salt waste contained in Drum 68660 does not exist. However, the TAT Report (2015) discussed the analysis of nitrate salt samples 
taken from two unprocessed drums, produced by the same process in the nineteen-eighties, and indicated that the predominant metals expected to be in Drum 68660 include the alkali $(\mathrm{Na}, \mathrm{K})$ and alkaline earth $(\mathrm{Mg}, \mathrm{Ca})$ elements with minor amounts of other transition metal $(\mathrm{Fe}, \mathrm{Cr}, \mathrm{Ni}$, $\mathrm{Zn})$, main group $(\mathrm{Al}, \mathrm{Pb})$, and actinide elements. The radiological constituents in the drum include ${ }^{241} \mathrm{Am},{ }^{243} \mathrm{Am},{ }^{237} \mathrm{~Np},{ }^{238} \mathrm{Pu},{ }^{239} \mathrm{Pu},{ }^{240} \mathrm{Pu},{ }^{241} \mathrm{Pu}$, and ${ }^{242} \mathrm{Pu}$, and the total radiological inventory in the drum was estimated to be 4.81Ci (TAT-Report, 2015 and DOE, 2015a)). These analytical results suggested that the isotopes of ${ }^{241} \mathrm{Am}$ and ${ }^{239} \mathrm{Pu}$ and ${ }^{241} \mathrm{Pu}$ accounted for more than $99 \%$ of the Drum 68660 's radioactive inventory.

\section{Results and Discussion}

\section{Actinide concentrations in underground air}

The airborne radioactivity detected in WIPP underground air just before (Station A) and after the HEPA filtration (Station B) is shown in Tables 1 and 2. The analysis of these filters is designed to show how well the HEPA filters worked to trap the underground radiation-bearing airborne particulates, but they also showed some amount of leakage around the filters, leakage that was addressed by sealing baffles with foam. The analytical results show that the airborne activity was primarily ${ }^{241} \mathrm{Am}$, followed by ${ }^{241} \mathrm{Pu}$ and ${ }^{239} \mathrm{Pu}$. The values detected at Station $\mathrm{A}$ and Station B are considerably higher than those historically measured for these Stations. The filter removed the morning after the event at Station A (before exhaust air enters the HEPA filter) showed high levels of radioactivity, as expected, about $3.06 \times 10^{5} \mathrm{~Bq}$ of ${ }^{241} \mathrm{Am}, 8.40 \times 10^{3} \mathrm{~Bq}$ of ${ }^{241} \mathrm{Pu}$, and $4.74 \times 10^{4} \mathrm{~Bq}$ of ${ }^{239+240} \mathrm{Pu}$ (Figure 3 ). The sample collected the very next day showed about $8.66 \times 10^{3} \mathrm{~Bq}$ of ${ }^{241} \mathrm{Am}, 3.42 \times 10^{2} \mathrm{~Bq}$ of ${ }^{241} \mathrm{Pu}$, and $1.37 \times 10^{3} \mathrm{~Bq}$ of ${ }^{239+240} \mathrm{Pu}$. By the morning of February 21, these levels had dropped to about $10 \mathrm{~Bq}$ of combined $\mathrm{Pu}$ and $\mathrm{Am}$. The sharp spike and subsequent decline in radiation are suggestive of a single release of contamination on February 14. It is important to note that these high activity values are reflective of what was detected in the unfiltered underground air prior to going through HEPA filtration systems and do not represent the activity levels that ultimately escaped to the environment.

The amount of radioactivity measured at Station B (exhaust air after HEPA filtration, sampling the amount that was ultimately released into the environment) were much lower, about $8.42 \times 10^{2} \mathrm{~Bq}$ of ${ }^{241} \mathrm{Am}, 7.87 \times 10^{1} \mathrm{~Bq}$ of ${ }^{241} \mathrm{Pu}$, and $8.27 \times 10^{1} \mathrm{~Bq}$ of ${ }^{239+240} \mathrm{Pu}$ (Figure 4) when it was collected on February 18, almost four days after the release. By February 21, a Station B 
sample had only about $1 \mathrm{~Bq}$ of combined $\mathrm{Am}$ and $\mathrm{Pu}$. As the levels of ${ }^{241} \mathrm{Am}$ and ${ }^{239+240} \mathrm{Pu}$ in the WIPP exhaust air both before and after the HEPA filtration continued to remain low beginning April 22, 2014, daily filter analysis was discontinued and a weekly composite filter sample began to be used for the determination of actinides.

\section{Detection of Minor Radionuclides}

To a lesser extent, isotopes of ${ }^{238} \mathrm{Pu},{ }^{228} \mathrm{Th},{ }^{234} \mathrm{U}$, and ${ }^{137} \mathrm{Cs}$ were also detected in the WIPP underground air samples. However, these isotopes were not as consistently detected as ${ }^{241} \mathrm{Am}$ and ${ }^{239+240} \mathrm{Pu}$. For example, the ${ }^{137} \mathrm{Cs}$ was detected only once at a Station A filter, but was not detected in any of the post-HEPA air filters collected from Station B. The detection of ${ }^{238} \mathrm{Pu}$ persisted for about a week. The highest levels of ${ }^{238} \mathrm{Pu}$ detected were $2.14 \times 10^{3} \mathrm{~Bq}$ at Station A (Pre-HEPA) and $1.19 \times 10^{1} \mathrm{~Bq}$ at Station B (Post-HEPA) filters measured on filters collected on February 14, 2014. Similarly, the highest levels of isotopes of thorium and uranium were measured on those same filter samples. These results show that the HEPA filters trapped most of the radioactivity. There never was an amount released that exceeded regulatory limits, and there is no reason to suspect there will be any environmental impact from this minor external release event.

\section{Source Term Determination}

To assess the magnitude of the accident and potential radiological doses received by the general populations, it is important to estimate the source term of the radiological release into the environment. Since the air in the repository exits to the surface through the exhaust shaft, this shaft is the sole potential pathway for airborne radioactivity release from the WIPP during the operational phase. So, in the source term estimation, the station B airborne concentration data for $\mathrm{Am}$ and $\mathrm{Pu}$ isotopes was used. Summing all isotopes ( $\mathrm{Pu}$ and $\mathrm{Am})$ measured over the first week after the event, and taking into account the total air flow through the HEPA filters as $1699 \mathrm{~m}^{3}$ per minute and that the station B air sampler draws $0.06 \mathrm{~m}^{3}$ per minute, the source term based on CEMRC data was estimated as $2.53 \times 10^{7} \mathrm{~Bq}$ of ${ }^{241} \mathrm{Am}, 3.06 \times 10^{6} \mathrm{~Bq}$ of ${ }^{241} \mathrm{Pu}$ and $2.48 \times 10^{6} \mathrm{~Bq}$ of ${ }^{239+240} \mathrm{Pu}$, summing to a total release of $\sim 0.83 \mathrm{mCi}$. The total estimated release based on NWP analyses of the station B filters (DOE, 2015b) was calculated as $4.51 \times 10^{7} \mathrm{~Bq}$ of ${ }^{241} \mathrm{Am}, 2.94 \times 10^{6}$ of ${ }^{241} \mathrm{Pu}$, and $2.52 \times 10^{6} \mathrm{~Bq}$ of ${ }^{239+240} \mathrm{Pu}$, suggesting a total release of $\sim 1.3 \mathrm{mCi}$ ). This source term 
is dominated by ${ }^{241} \mathrm{Am}(>90 \%)$. Without further information, it is difficult to determine which of these analyses is to be preferred.

\section{Actinide concentrations in ambient air}

Ambient air filter samples collected from sampling stations on and near the WIPP facility by CEMRC confirmed brief detection of trace amounts of ${ }^{241} \mathrm{Am}$ and ${ }^{239+240} \mathrm{Pu}$ at two sampling locations (Onsite and Near Field). A third ambient air- filter station at Cactus Flats showed no detectable americium or plutonium. The highest levels detected were $1.3 \mathrm{~Bq}$ (or $115.2 \mu \mathrm{Bq} / \mathrm{m}^{3}$ )

for ${ }^{241} \mathrm{Am}$ and $0.11 \mathrm{~Bq}$ (or $10.2 \mu \mathrm{Bq} / \mathrm{m}^{3}$ ) for ${ }^{239+240} \mathrm{Pu}$ at the Onsite sampling station, and $0.65 \mathrm{~Bq}$ $\left(81.4 \mu \mathrm{Bq} / \mathrm{m}^{3}\right)$ for ${ }^{241} \mathrm{Am}$ and $0.05 \mathrm{~Bq}\left(5.78 \mu \mathrm{Bq} / \mathrm{m}^{3}\right)$ for ${ }^{239+240} \mathrm{Pu}$ at the Near Field station. A week after the event, the radiation at these stations had decreased by a hundred times, and two weeks later the radiation levels at these stations were back to the pre-release levels and sometimes not even detectable, demonstrating no continuing contamination and suggesting there to be no long-term environmental impact. There was no risk to anyone who might have been near these sampling locations from these low contamination levels.

The weekly ambient air samples collected by NWP (DOE, 2014c) also detected trace levels of ${ }^{241} \mathrm{Am}$ and ${ }^{239+240} \mathrm{Pu}$ at four sampling locations. The highest levels detected were $0.81 \mathrm{~Bq}$ for ${ }^{241} \mathrm{Am}$ and $0.061 \mathrm{~Bq}$ for ${ }^{239+240} \mathrm{Pu}$ at the WIPP Far Field (WFF) sampling station. The levels of these radionuclides above MDC were detected only twice. The current levels at all sampling locations is below the MDC. The levels of ${ }^{239+240} \mathrm{Pu}$ and ${ }^{241} \mathrm{Am}$ concentrations in ambient air around the WIPP vicinity both before and after the February 14 radiation release event are shown in Figures 5 and 6.

Air concentration data collected during the first week of the accident were utilized to estimate the potential dose received by workers and the public. The particles were conservatively assumed to be in the respirable range of 0.1 to 10 microns. Although the release was determined to be mostly $\mathrm{Am}$ and some $\mathrm{Pu}, 100 \% \mathrm{Pu}$ was assumed because it has a higher ICRP 60 dose conversion factor and would result in a more conservative dose estimate. According to these dose estimates, the largest potential dose was at the site boundary, where a maximum dose of around $0.03 \mathrm{mSv}$ was possible if a person stood by the air sampler for the full 15 hour sampling time. There are no nearby cities or settlements in the WIPP vicinity; there is one ranch nearby, at the property-protection site boundary, with a house that is not occupied full-time. According to 
the dose modeling performed, the nearest rancher would have received $0.0002 \mathrm{mSv}$ of a lifetime exposure from the WIPP release (Hayes, 2014). As a comparison, the annual natural radiation dose at the elevation of WIPP (about 1,000 meters above sea level) is around $3.10 \mathrm{mSv}$. Natural radiation sources include soil and rocks, certain building materials, cosmic rays, some foods, radon and radiation sources in our bodies and plants. The DOE and international radiation protection organizations recommend a $1 \mathrm{mSv}$ annual maximum additional dose limit for the general public and a $0.05 \mathrm{~Sv}$ annual maximum additional dose limit for radiation workers. The average person living in the United States receives an annual dose of about $6.2 \mathrm{mSv}$ from exposure to naturally occurring and medical sources of radiation.

\section{Activity Ratio}

The activity ratios of ${ }^{238} \mathrm{Pu} /{ }^{239+240} \mathrm{Pu},{ }^{241} \mathrm{Pu} /{ }^{239+240} \mathrm{Pu}$, and ${ }^{241} \mathrm{Am} /{ }^{239+240} \mathrm{Pu}$ vary according to the source, so they can act as a fingerprint to identify the origin of the plutonium from different sources released into the environment. The ${ }^{238} \mathrm{Pu} /{ }^{239+240} \mathrm{Pu},{ }^{241} \mathrm{Pu} /{ }^{239+240} \mathrm{Pu}$, and ${ }^{241} \mathrm{Am} /{ }^{239+240} \mathrm{Pu}$ activity ratios measured in a variety of sample media after the release event are shown in Table 3. The ${ }^{241} \mathrm{Am} /{ }^{239+240} \mathrm{Pu}$ ratio at Station A varied from 4.81 to 20.67 on separate days during the progression of the event, while the corresponding ratio at Station B varied in the range 2.95 to 16.26, but the average ratios at both the Stations remained relatively constant, around 10, even though the data showed a relatively wide range.

A similar variation in ${ }^{241} \mathrm{Am} /{ }^{239} \mathrm{Pu}$ activity ratio was also observed in the early post-event filter samples collected from Station A and Station B by NWP (Table 3). The ${ }^{241} \mathrm{Am} /{ }^{239} \mathrm{Pu}$ ratios in their samples were shown to vary from 1.63 to 27.62 at Station A and from 5.13 to 18.03 at Station B during the course of the event, but the average ratios remain fairly constant, about 10 at both the Stations.

The post event analysis of underground CAM-151 filters measured by Savannah River National Laboratory (SRNL) showed ${ }^{241} \mathrm{Am} /{ }^{239} \mathrm{Pu}$ ratios in the range 12.1 to 22.2 (Table 3). In addition, air sampled from Fixed Air sampler, FAS-118, which sampled the airborne activity at the inlet to Panel 7, upstream of CAM-151 and the event area, were collected and analyzed. The FAS-118 filter had ${ }^{241} \mathrm{Am} /{ }^{239} \mathrm{Pu}$ activity ratios of 26.3. The contamination on the FAS-118 filter was likely due to a momentary back-pulse of airflow during the ventilation change and/or release 
of materials into the air flow. These results are very similar to the ratios measured in Station A and Station B for the same period.

The ${ }^{241} \mathrm{Am} /{ }^{239} \mathrm{Pu}$ ratios measured in sampling materials (swipes, smear and debris ejected from the breached drum) collected from the immediate vicinity of the breached drum in Room 7 of Panel 7, showed significantly lower ratios than those measured on CAM-151, FAS-118, Station $\mathrm{A}$ and Station $\mathrm{B}$. The ${ }^{241} \mathrm{Am} /{ }^{239} \mathrm{Pu}$ activity ratio in the swipe samples collected from Panel 7 were in the range of 9.0-10.2, while those of debris samples from panel 7 had ${ }^{241} \mathrm{Am} /{ }^{239} \mathrm{Pu}$ ratios in the range 1.94-5.15 with a mean value of 5.24 (Table 3 ). These values agree with the ${ }^{241} \mathrm{Am} /{ }^{239} \mathrm{Pu}$ activity ratio of 4.75 estimated for the bulk contents of the breached drum. The ${ }^{241} \mathrm{Am} /{ }^{239} \mathrm{Pu}$ activity ratio analyses conducted on a variety of sampled media following the radiation release event reveals that the lowest ratios were measured closest to the source and the ratio increases with distance from the source (Table 3 ). This deviation in ratios can be attributed to the potential fractionation of the ${ }^{241} \mathrm{Am}$ and ${ }^{239} \mathrm{Pu}$ isotopes during the event and the airborne transport through the WIPP facility and out via the ventilation system. Given the different chemical and physical properties of the two elements, such fractionation is to be expected.

Additionally, the process (anion exchange or oxalate precipitation) used to produce the waste salts is also a contributing factor in the difference in ratios between the bulk contents of the drum and the material ejected. When an anion-exchange process is used to recover plutonium materials, the liquid effluent contains most of the Am. When that liquid effluent is run through the evaporation process, it produces salt with high $\mathrm{Am} / \mathrm{Pu}$ ratios. When an oxalate precipitation process is used, plutonium is precipitated with oxalic acid post ion-exchange. The filtrate from the oxalate precipitation step is therefore very low in Am and when these liquids go through the evaporation process the resultant salt has a low $\mathrm{Am} / \mathrm{Pu}$ ratio.

Unlike the ${ }^{241} \mathrm{Am} /{ }^{239+240} \mathrm{Pu}$ ratio which varied substantially during the course of the event, the ${ }^{241} \mathrm{Pu} /{ }^{239+240} \mathrm{Pu}$ activity ratio remained fairly constant, largely between $0.18-5.14$ at Station $\mathrm{A}$ and 0.94-5.47 at Station B, indicating plutonium isotopes detected were dominated primarily by contributions from weapons-grade plutonium. The measured ${ }^{241} \mathrm{Pu} /{ }^{239+240} \mathrm{Pu}$ ratios were consistent with those expected to be present in the breached drum. The ${ }^{241} \mathrm{Pu} /{ }^{239+240} \mathrm{Pu}$ ratios of weapons grade plutonium from different nuclear weapon devices tested between 1945 to 1963 were shown to vary from 0.75-7.5 (Irlweck and Hrnecek, 1990). Holm (1995) reported an 
average ${ }^{241} \mathrm{Pu} /{ }^{239+240} \mathrm{Pu}$ ratio of about 4 in the samples contaminated with weapons grade plutonium and 16 in fallout samples.

In the 1960s Palomares plane crash which destroyed two nuclear bombs, hot particles sampled had ${ }^{241} \mathrm{Pu} /{ }^{239+240} \mathrm{Pu}$ ratios between $5.7 \pm 1.5$ to $14.0 \pm 1.5$, with an overall mean of $9.6 \pm 2.7$ (reference date 1966-see Table 4). Romero et al., 1991, reported a ratio of 1.42 \pm 0.46 (reference date 1989-see Table 4) in river sediment and 2.6 \pm 0.5 (reference date August, 1993-see Table 4) in marine sediment samples originating from the Palomares accident. Similar ${ }^{241} \mathrm{Pu} /{ }^{239+240} \mathrm{Pu}$ activity ratios (3.3-8.4) were measured in the hot particles originating from Thule, Greenland, bomb debris from another aircraft crash in the 1960s, 12 miles out to sea from Thule (Mitchell et al., 1997). Erickson et al, 2008 analyzed five isolated Thule hot particles and marine sediment samples and reported a mean ratio of 0.87 1.2 (range 0.75-1.06, reference date, 2001-see Table 4). Further, the activity ratio of ${ }^{241} \mathrm{Pu} /{ }^{239+240} \mathrm{Pu}$ in the BOMARC (McGuire Air Force Base and Boeing Michigan Aeronautical Research Center) soil was found to be in the range of 0.79-1.29 (Lee and Clark, 2005) with a mean value of 1.0. For comparison purposes, the ${ }^{241} \mathrm{Pu} /{ }^{239+240} \mathrm{Pu}$ activity ratios in different nuclear weapon devices are summarized in Table 4 . These results can be used to illustrate the role of transport, by air or water, in changing the isotope ratios found as a function of distance from the source.

The ${ }^{238} \mathrm{Pu} /{ }^{239+240} \mathrm{Pu}$ activity ratio at Station $\mathrm{A}$ and Station $\mathrm{B}$ remained fairly constant during the course of the event Figure 7). The ${ }^{238} \mathrm{Pu} /{ }^{239+240} \mathrm{Pu}$ activity ratio at Station A was found to be in the range of $0.03-0.10$ with a mean value of 0.05 , while the corresponding ratio at Station B varied between $0.028-0.214$ with a mean value of 0.053 . Furthermore, analyses of filter samples collected by NWP showed ${ }^{238} \mathrm{Pu} /{ }^{239} \mathrm{Pu}$ a mean activity ratio of 0.048 (range $0.003-0.080$ ) at Station A and 0.050 (range 0.003-0.273) at Station B, which is in good agreement with the values estimated for the bulk content of the breached drum $\left({ }^{238} \mathrm{Pu} /{ }^{239} \mathrm{Pu}\right.$ activity ratio of 0.045 and ${ }^{238} \mathrm{Pu} /{ }^{239+240} \mathrm{Pu}$ activity ratio of 0.037$)$.

The activity ratio of ${ }^{238} \mathrm{Pu} /{ }^{239+240} \mathrm{Pu}$ has been demonstrated to be useful in fingerprinting various plutonium sources in the environment. For example, the ${ }^{238} \mathrm{Pu} /{ }^{239+240} \mathrm{Pu}$ activity ratio is approximately $0.014-0.42$ for weapons grade plutonium, 0.026 for global fallout from nuclear tests, 0.25 for releases from nuclear fuel reprocessing plants, $0.49-0.56$ for Chernobyl fallout and 1.07-2.89 for Fukushima fallout. Further, the mean ${ }^{238} \mathrm{Pu} /{ }^{239+240} \mathrm{Pu}$ activity ratio in the Thule samples was found to be $0.015 \pm 0.001$, while the corresponding ratio in the Palomares samples 
was $0.0275 \pm 0.0012$. In the BOMARC soil, the activity ratio of ${ }^{238} \mathrm{Pu} /{ }^{239+240} \mathrm{Pu}$ was reported to be in the range of 0.017-0.033 with a mean value of 0.024. In addition, emissions of actinides from nuclear reprocessing plants exhibit a tenfold higher ${ }^{238} \mathrm{Pu} /{ }^{239+240} \mathrm{Pu}$ ratio compared to global fallout, such as 0.30 for releases at Marcoule in France.

At the present time, the typical ratios of ${ }^{238} \mathrm{Pu} /{ }^{239+240} \mathrm{Pu}$ that originated from the weapons grade plutonium and those that originated from the global nuclear weapons test fallout are so similar that it is difficult to unambiguously identify the source of plutonium based on this ratio alone. The ${ }^{240} \mathrm{Pu} /{ }^{239} \mathrm{Pu}$ atom ratio is a better indicator to distinguish fallout plutonium from the weapons grade plutonium because the ${ }^{240} \mathrm{Pu} /{ }^{239} \mathrm{Pu}$ atom ratio in global fallout $(\sim 0.18)$ differs significantly from the weapons grade plutonium ratio of $\sim 0.05$. Table 4 lists the ${ }^{240} \mathrm{Pu} /{ }^{239} \mathrm{Pu}$ atom ratios for different plutonium sources in the environment.

In contrast to the ratio of isotopes of the different elements, the ratio of isotopes of the same elements such as ${ }^{241} \mathrm{Am} /{ }^{243} \mathrm{Am}$ or ${ }^{240} \mathrm{Pu} /{ }^{239} \mathrm{Pu}$ remain fairly constant across the breached drum and the various media samples, and are likely better indicators of radioactive materials released from the WIPP. The ${ }^{240} \mathrm{Pu} /{ }^{239} \mathrm{Pu}$ and ${ }^{241} \mathrm{Am} /{ }^{243} \mathrm{Am}$ atom ratios determined in the debris and swipe sample taken from Room 7 of Panel 7 following the radiation release event are listed in Table 3. These ratios were fairly consistent across the breached drum and the various media samples.

Given the variability in the historical processing and post-event measured ${ }^{241} \mathrm{Am} /{ }^{239} \mathrm{Pu}$ ratios, we recommend that although in a general sense the $\mathrm{Am} / \mathrm{Pu}$ signature could be used to distinguish radioactive materials released from this particular WIPP accident, the ${ }^{240} \mathrm{Pu} /{ }^{239} \mathrm{Pu}$ and ${ }^{241} \mathrm{Am} /{ }^{243} \mathrm{Am}$ ratios are much more reliable signatures being the two dominant elements in the waste stream involved in this release event. This waste stream, however, is not typical in terms of the isotopic composition of the various waste streams being disposed of in the WIPP repository. Isotopes of the same elements will behave similarly, both chemically and physically, and therefore obviate any variability due to fractionation.

\section{Conclusion}

After almost fifteen years of safe and efficient operations, the WIPP repository had one of its waste drums ruptured underground as a result of a runaway chemical reaction within the drum. The contents of the drum that breached underground were chemically incompatible, and a runaway reaction ensued that produced prodigious amounts of heat and gases, causing the 
drum's lid to deform and open, releasing some portion of the content of the drum into the WIPP underground. Most of the radioactivity released in the WIPP underground was contained by the ventilation system's filter banks. A small portion of the contaminated underground air also escaped to the surface through imperfectly sealing dampers and was detected approximately one kilometer away from the facility.

According to source-term estimates, the actual amount of radioactivity released from the WIPP site was less than 1.5 millicurie. The dominant radionuclides released were americium and plutonium, in a ratio that matches the content of the breached drum. The highest activities detected outside were $115.2 \mu \mathrm{Bq} / \mathrm{m}^{3}$ for ${ }^{241} \mathrm{Am}$ and $10.2 \mu \mathrm{Bq} / \mathrm{m}^{3}$ for ${ }^{239+240} \mathrm{Pu}$ at a sampling station located 91 meters away from the underground air exhaust point and $81.4 \mu \mathrm{Bq} / \mathrm{m}^{3}$ of ${ }^{241} \mathrm{Am}$ and $5.8 \mu \mathrm{Bq} / \mathrm{m}^{3}$ of ${ }^{239+240} \mathrm{Pu}$ at a monitoring station located approximately one kilometer northwest of the WIPP facility. The levels detected were very low and localized, and no radiation-related health effects among local workers or the public would be expected. A week after the event, the airborne radioactive particulate levels at these stations had decreased by a hundred times, and two weeks later the levels at these stations were back to the pre-release levels and sometimes not even detectable, demonstrating no long-term environmental contamination. In terms of radiological risk at or in the vicinity of the WIPP site, the increased risk from the WIPP releases is exceedingly small, approaching zero. 


\section{References}

DOE, 2012. Waste Isolation Pilot Plant Annual Site Environmental Report (ASER) for 2011.

DOE/WIPP-12-3489, U.S. Department of Energy. Accessible at:

http://www.wipp.energy.gov/information repository/cra/CRA-

2014/References/Others/US_DOE_2012_WIPP_Annual_Site_Environmental_Report 20

11_DOE_WIPP_12_3489.pdf

DOE, 2014a. U.S. Department of Energy- Accident Investigation Board (AIB) Report,

Underground Salt Haul Truck Fire at the Waste Isolation Pilot Plant, February 5, 2014.

Washington, DC: U.S. Department of Energy. Accessible at:

http://www.wipp.energy.gov/Special/AIB\%20Report.pdf

DOE, 2014b. U.S. Department of Energy Accident Investigation Report, Phase-I. Radiological

Release Event at the Waste Isolation Pilot Plant on February 14, 2014. Washington, DC:

U.S. Department of Energy. Accessible at:

http://www.wipp.energy.gov/Special/AIB_Final_WIPP_Rad_Release_Phase1_04_22_2014.pdf

DOE, 2014c. Waste Isolation Pilot Plant Annual Site Environmental Report (ASER) for 2014.

DOE/WIPP-15-8866, Washington, D.C., U.S. Department of Energy.

DOE, 2015a. U.S. Department of Energy Accident Investigation Report, Phase -II. Radiological

Release Event at the Waste Isolation Pilot Plant on February 14, 2014. Washington, DC:

U.S. Department of Energy. Accessible at:

http://www.wipp.energy.gov/Special/AIB_WIPP\%20Rad_Event\%20Report_Phase\%20II.pdf

DOE, 2015b. U.S. Department of Energy, WIPP Waste Isolation Pilot Plant Recovery web site, accessed 09-29-2015, http://www.wipp.energy.gov/Special/Station\%20B.pdf

Douglas, R.L., 1978. United States Environmental Protection Agency Office of Radiation Programs-Las Vegas facility technical note ORP/LV-78-3.

Eriksson, M., Lindahl , P., Roos, P., Dahlgaard, H., Holms, E., 2008. U, Pu, and Am Nuclear Signatures of the Thule Hydrogen Bomb Debris, Environ. Sci. Technol. 42, 4717-4722 .

Hayes, R. 2014. February $14^{\text {th }}$, contamination release consequence assessment. Rev. 1," March 2014, Nuclear Waste Partnership, available online at: http://www.wipp.energy.gov/Special/Modeling\%20Results.pdf

Hindman, F.D., 1983. Neodymium fluoride mounting for alpha spectrometric determination of uranium, plutonium and americium. Anal. Chem. 55, 2460-2461.

Holm, E., 1995. Plutonium in the Baltic Sea. Appl. Radiat. Isot., 46, 1225-1229.

Irlweck, K., Hrnecek, E., 1990. ${ }^{241}$ Am concentration and ${ }^{241} \mathrm{Pu} /{ }^{239}\left({ }^{240}\right) \mathrm{Pu}$ ratios in soils contaminated by weapons-grade plutonium, J. Radioanal. Nucl. Chem. 138, 241-256. 
Kelly, J.M., Bond, L.A., Beasley, T.M., 1999. Global distribution of Pu isotopes and ${ }^{237}$ Np. Sci. Total Environ. 237/238, 483-500.

Komura, K., Sakamoue, M., 1984. Determination of ${ }^{240} \mathrm{Pu} /{ }^{239} \mathrm{Pu}$ ratio in environment samples based on the measurement of Lx/ $\alpha$-ray activity ratio. Health Phys. 46, 1213-1219.

Krey, P.W., Hardy, E.P., Pachucki, C., Rourke, F., Coluzza. J., Benson, W.K., 1976. Mass isotopic composition of global fallout plutonium in soil, transuranium nuclides in the environment, IAEA Sump. Proc. pp. 671-678.

Lansard, B., Charmasson, S., Gascó, C., Antón, M.P., Grenz, C., Arnaud, M. 2007. Spatial and temporal variations of plutonium isotopes $\left({ }^{238} \mathrm{Pu}\right.$ and $\left.{ }^{239,240} \mathrm{Pu}\right)$ in sediments off the Rhone River mouth (NW Mediterranean). Sci. Tot. Environ. 376, 215-227.

Lee, M.H., Clark, S.B., 2005. Activities of Pu and Am isotopes and isotopic ratios in a soil contaminated by weapons-grade plutonium, Environ Sci Technol. 1;39(15):5512-5516.

Litaor, M.I., 1999. Plutonium contamination in soils in open space and residential areas near Rocky Flats, Colorado. Health Phys. 76, 171-179.

Gross, M., S. Patchet, J. Davis, D. Ferguson, and R. Elmore, 2011. Representativeness of Sampling by Shrouded Probes in the Exhaust Shaft of the Waste Isolation Pilot Plant, Paper 11308 at WM2011 Conference, February 27 - March 3, 2011, Phoenix, AZ. Accessible at: http://www.wmsym.org/archives/2011/papers/11308.pdf

Mitchell, P., Vintró, L., Dahlgaard, H., Gascó, C., Sánchez-Cabeza, J.A., 1997. Perturbations in the ${ }^{240} \mathrm{Pu} /{ }^{239} \mathrm{Pu}$ global fallout ratio in local sediments following nuclear accidents at Thule (Greenland) and Palomares (Spain). Sci. Total Environ. 202, 147-153.

Muramatsu, Y., Ruhm, W., Yoshida, S., Tagami, K., Uchida, S., Wirth, E. 2000. Concentrations of ${ }^{239} \mathrm{Pu}$ and ${ }^{240} \mathrm{Pu}$ and their isotopic determined by ICP-MS in soils collected from the Chernobyl 30-km zone. Environ. Sci. Technol. 34, 2913-2917.

Muramatsu, Y., Uchida, S., Tagami, K., Yoshida, S., 2001. Measurement of ${ }^{240} \mathrm{Pu} /{ }^{239} \mathrm{Pu}$ isotopic ratios in soils from the Marshall Islands using ICP-MS, Sci. Total Environ. 278, 151-159.

Romero, L., Lobo, A.M., Holm, E., Sanchez-Cabeza, J.A. Transuranics contribution of Palomares coast: Tracing history and routes to the marine environment. In Radionuclides in the Study of Marine Processes , P. J. Kershaw, D.S. Woodhead (eds.) Elsevier Applied Science Publishing, London, 1991, Pp. 245.

Thakur, P., S. Ballard, S., Conca, J.L. 2011. Sequential isotopic determination of plutonium, thorium, americium and uranium in the air filter and drinking water samples around the WIPP site. J. Radioanal. Nucl. Chem. 387, 311-321. 
TAT-Report: Waste Isolation Pilot Plant Technical Assessment Team Report, March, 2015 http://www.wipp.energy.gov/Special/TECHNICAL_ASSESSMENT_TEAM_REPORT.p $\underline{\mathrm{df}}$

Yamamoto, M., Tsumura, A., Katayama, Y., Tsukatani, T., 1996. Plutonium isotopic composition in soil from the former Semipalatinsk nuclear test site, Radiochim. Acta 72, 209-215.

Yamamoto, M., Komura, K., Sakanoue, M. 1983. ${ }^{241}$ Am and plutonium in Japanese rice-field surface soils. J. Radiat. Res. 24, 237-249.

Zheng, J., Tagami, K. Uchida, S. 2013. Release of plutonium isotopes into the environment from the Fukushima Daiichi Nuclear Power Plant accident: What is known and what needs to be known. Environ. Sci. Technol. 47, 9584-9595. 


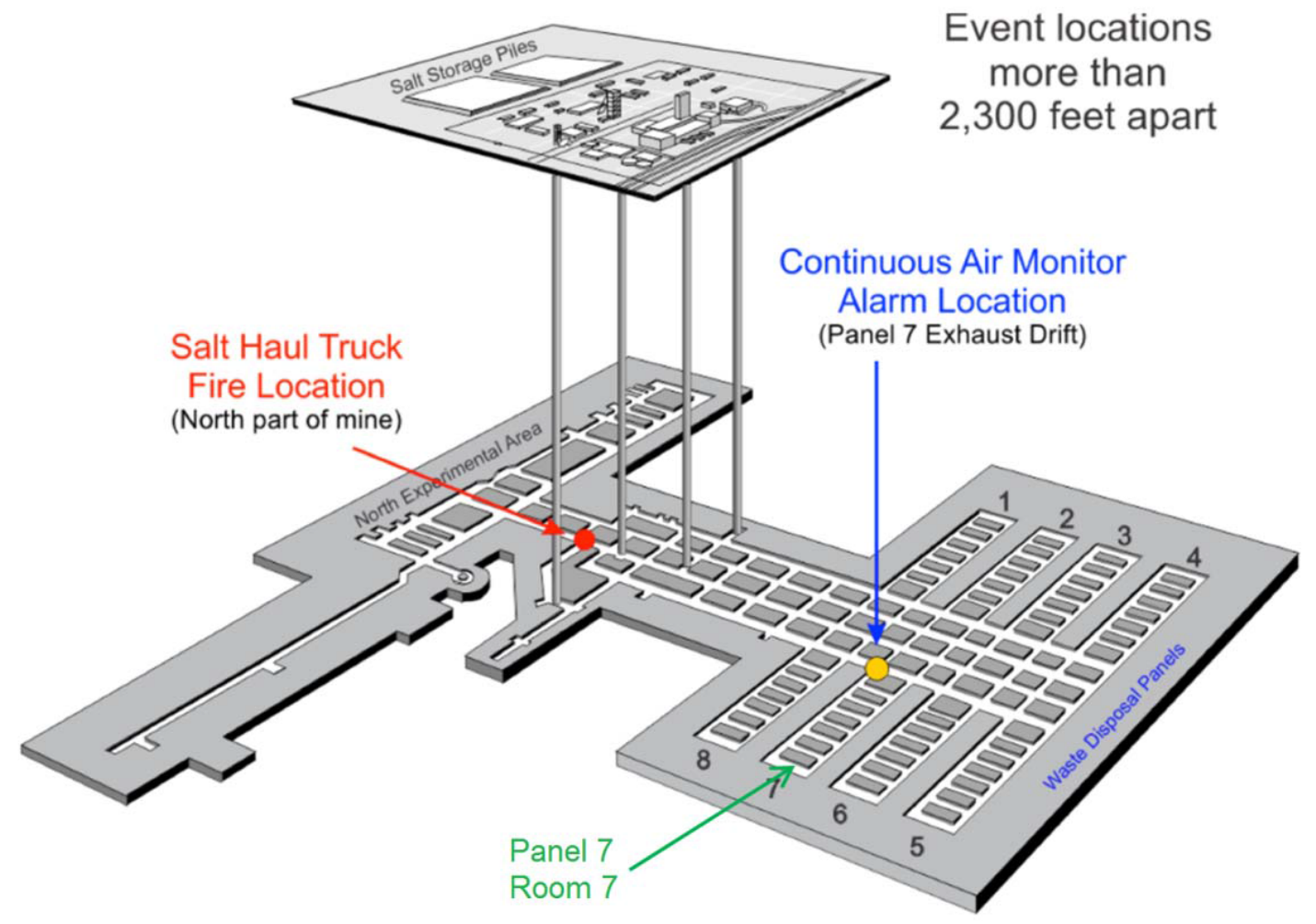

Figure 1. WIPP repository layout and February, 2014, event locations. 

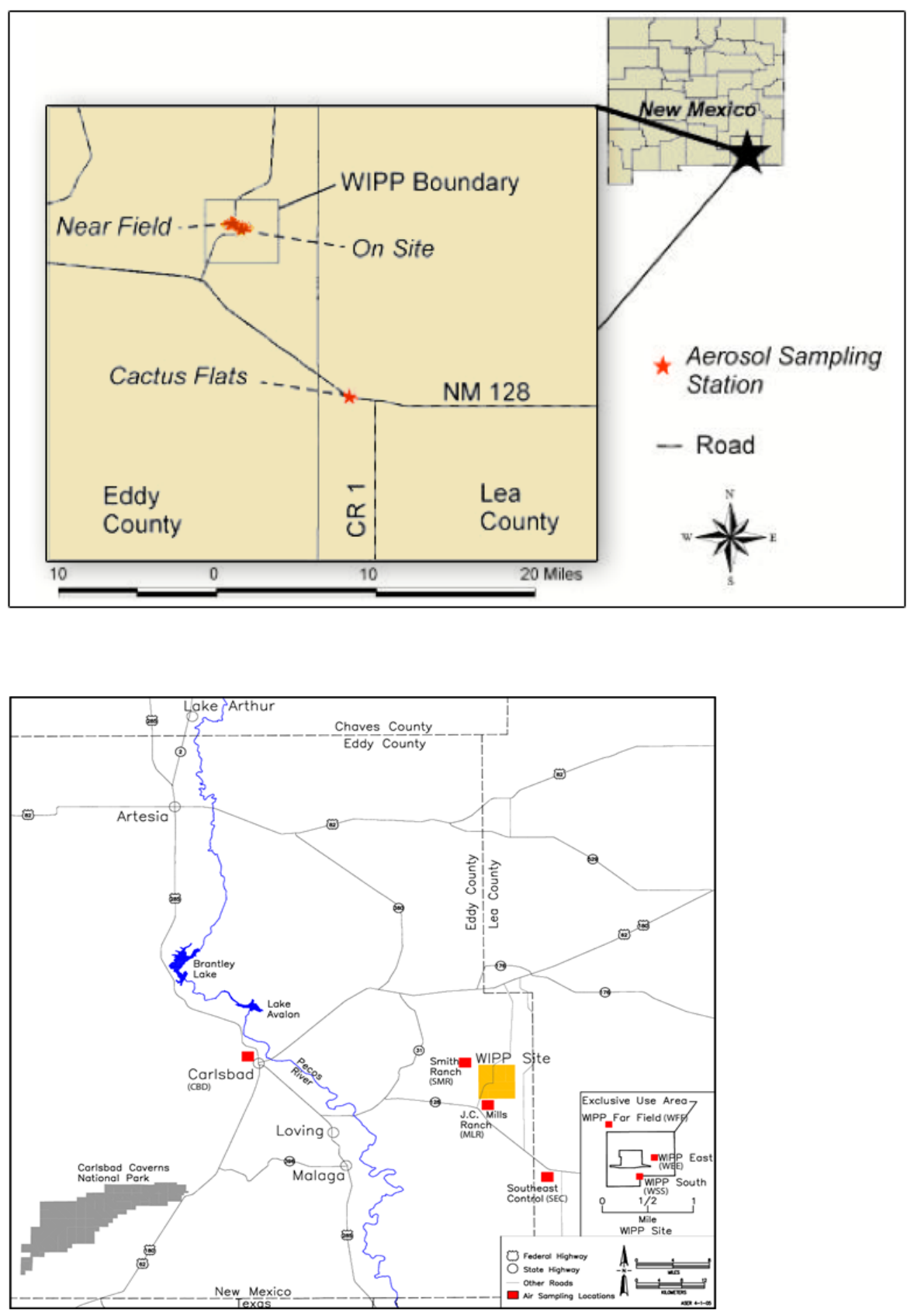

Figure 2. Ambient air sampling locations in the WIPP vicinity; CEMRC hi -vol sampling (Top) and NWP low volume sampling locations (Bottom) 


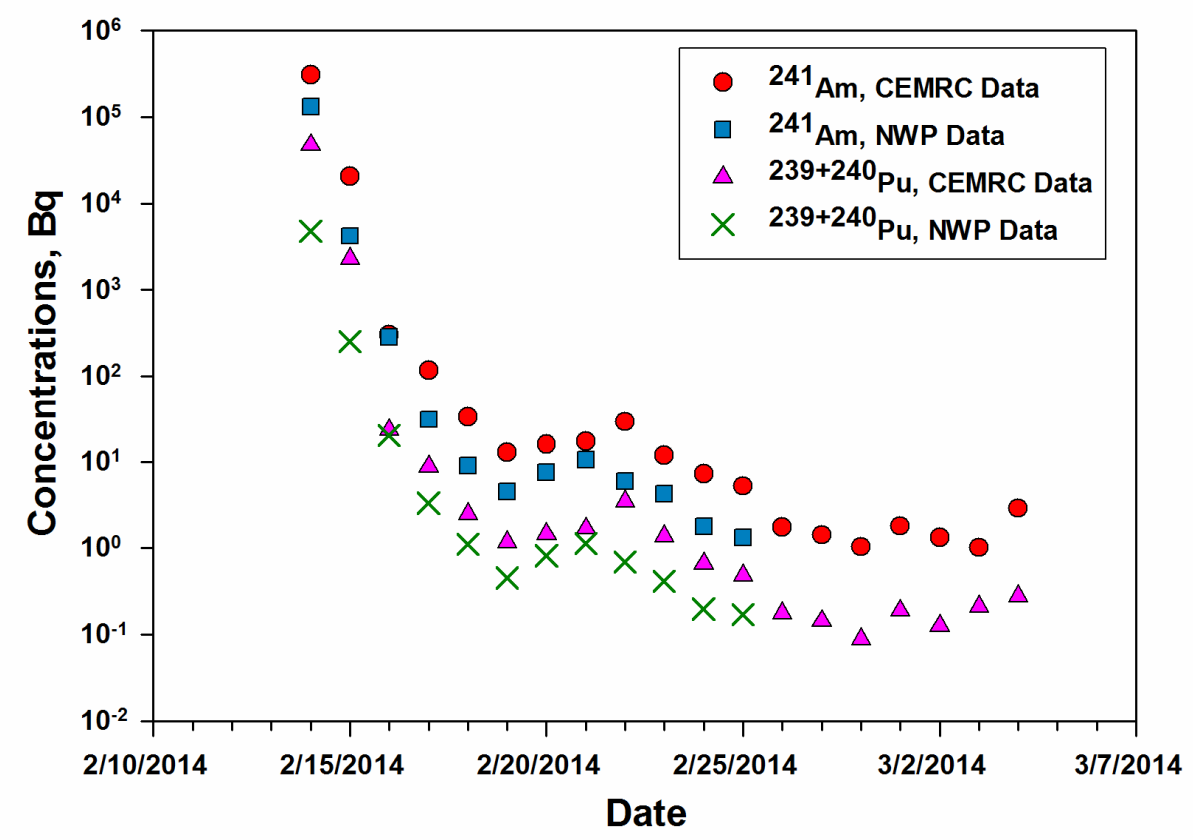

Figure 3. Concentrations of ${ }^{241} \mathrm{Am},{ }^{239+240} \mathrm{Pu}$ in the filter sample collected from Station $\mathrm{A}$ (Pre-HEPA) following the radiation release event at WIPP

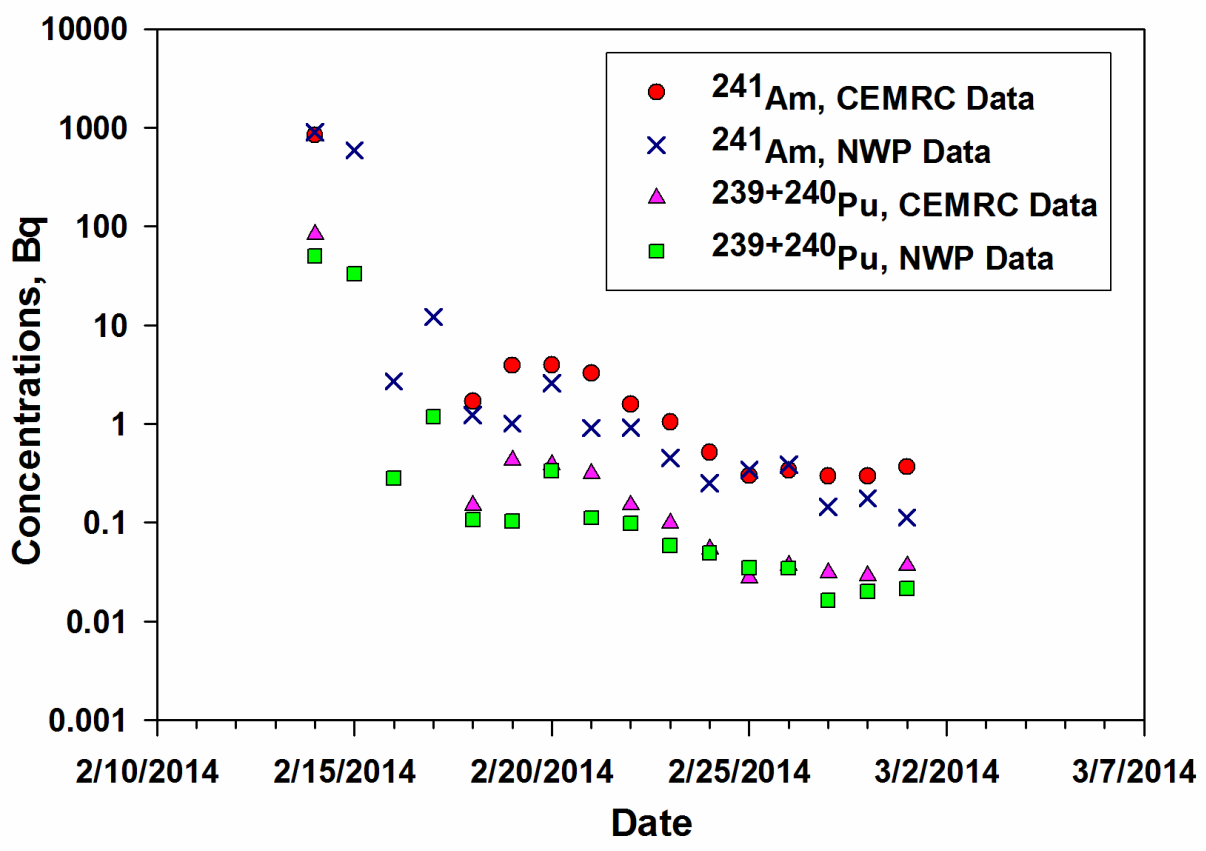

Figure 4. Concentrations of ${ }^{241} \mathrm{Am},{ }^{239+240} \mathrm{Pu}$ in the filter sample collected from Station $\mathrm{B}$ (Post-HEPA) following the radiation release event at WIPP 

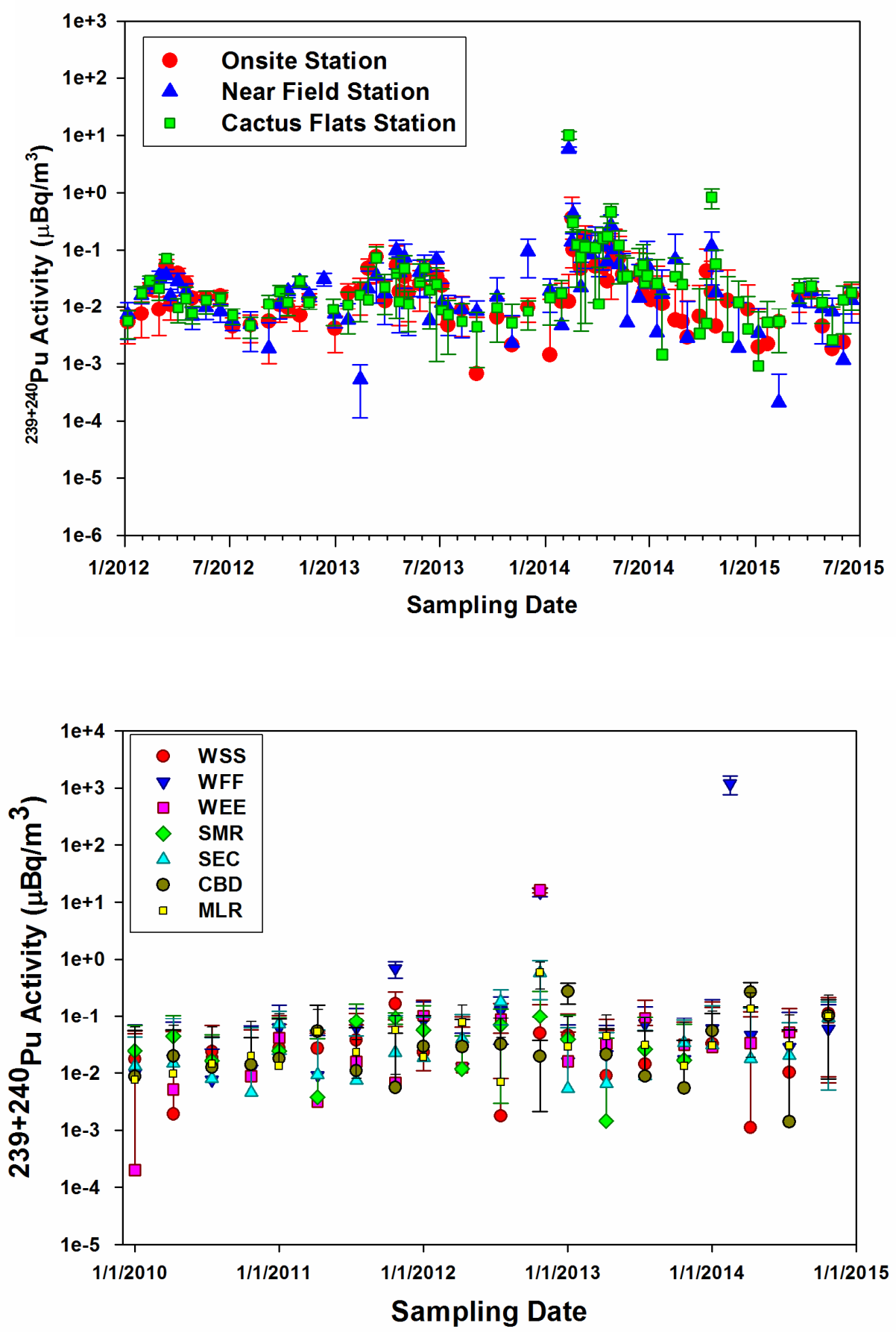

Figure 5: The ${ }^{239+240} \mathrm{Pu}\left(\mu \mathrm{Bq} / \mathrm{m}^{3}\right)$ concentrations in the ambient air in the WIPP vicinity; CEMRC hi-vol sampling data (Top) and NWP low-vol sampling data (Bottom). 

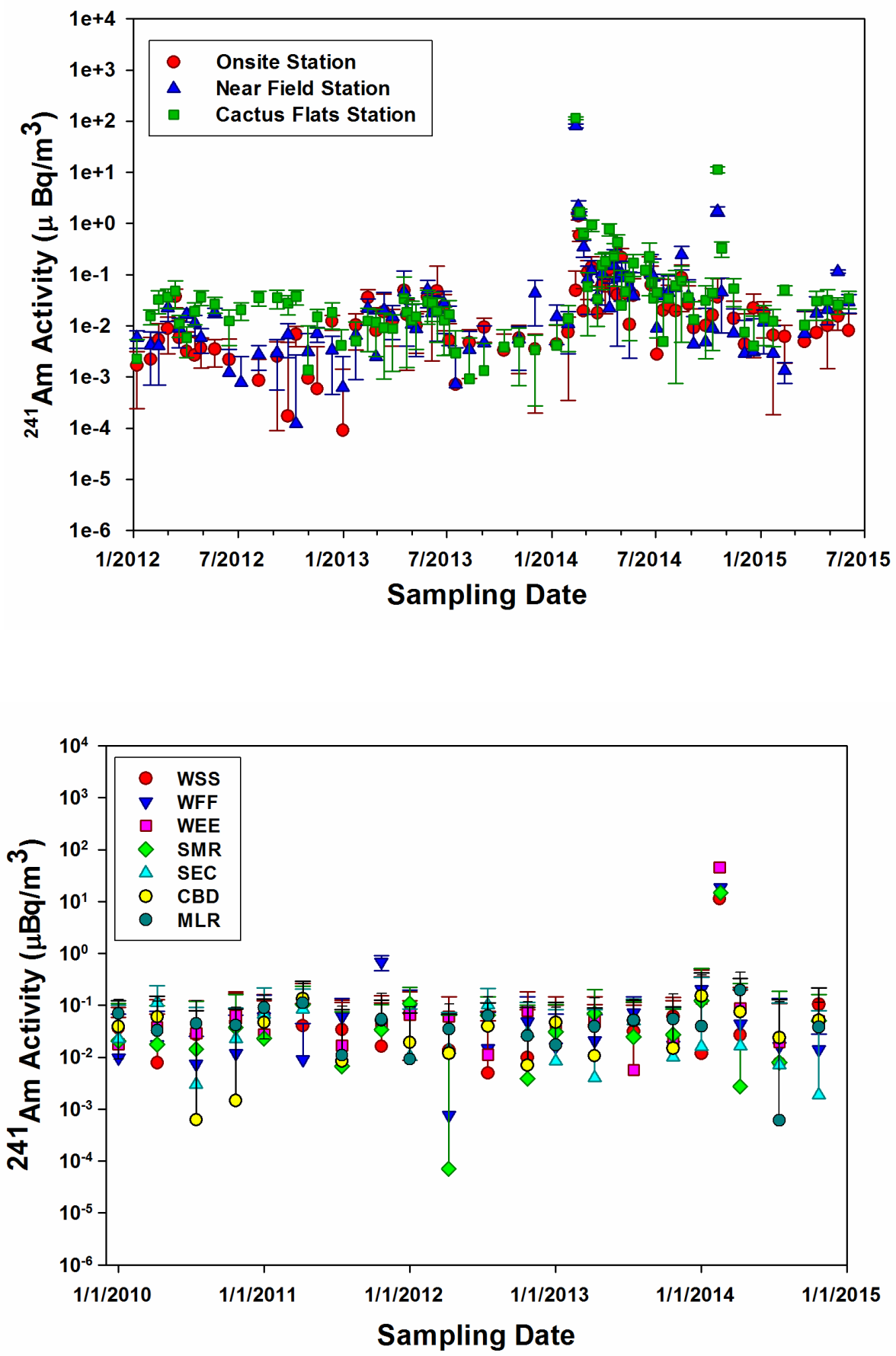

Figure 6: The ${ }^{241} \mathrm{Am}\left(\mu \mathrm{Bq} / \mathrm{m}^{3}\right)$ concentrations in the ambient air in the WIPP vicinity; CEMRC hi-vol sampling data (Top) and NWP low-vol sampling data (Bottom) 


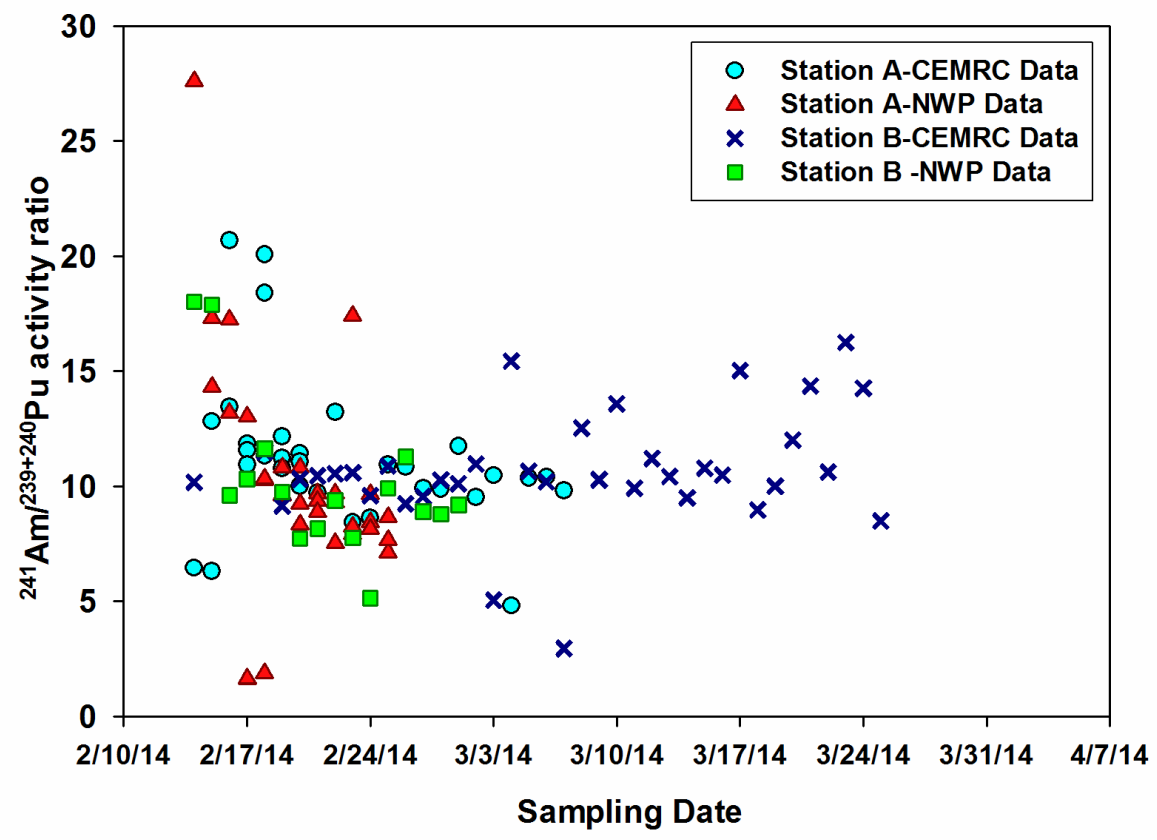

Figure 7. The ${ }^{241} \mathrm{Am} /{ }^{239+240} \mathrm{Pu}$ activity ratio measured in the WIPP underground air both before (Station A) and after HEPA (Station B) filtration. 
Table 1. The ${ }^{241} \mathrm{Am},{ }^{239+240} \mathrm{Pu},{ }^{238} \mathrm{Pu}$ and ${ }^{241} \mathrm{Pu}$ concentrations (Bq) in unfiltered underground air (Station $A$ ) following the February 14, radiation release event at the WIPP.

\begin{tabular}{cccccc}
\hline $\begin{array}{c}\text { Sample } \\
\text { Date }\end{array}$ & $\begin{array}{c}\text { Run } \\
\text { time, } \\
\text { min }\end{array}$ & ${ }^{241} \mathrm{Am}, \mathrm{Bq}$ & ${ }^{239+240} \mathrm{Pu}, \mathrm{Bq}$ & ${ }^{238} \mathrm{Pu}, \mathrm{Bq}$ & ${ }^{241} \mathrm{Pu}, \mathrm{Bq}$ \\
\hline $2 / 14 / 14$ & 1367 & $3.06 \times 10^{5} \pm 8.86 \times 10^{4}$ & $4.74 \times 10^{4} \pm 5.48 \times 10^{3}$ & $2.14 \times 10^{3} \pm 4.42 \times 10^{2}$ & $8.40 \times 10^{3} \pm 2.01 \times 10^{2}$ \\
$2 / 15 / 14$ & 130 & $8.66 \times 10^{3} \pm 2.74 \times 10^{3}$ & $1.37 \times 10^{3} \pm 1.74 \times 10^{2}$ & $72.0 \pm 21.8$ & $342 \pm 15.2$ \\
$2 / 15 / 14$ & 890 & $1.12 \times 10^{4} \pm 2.19 \times 10^{3}$ & $870 \pm 104$ & $37.6 \pm 9.2$ & $633 \pm 17.6$ \\
$2 / 15 / 14$ & 560 & $831.33 \pm 18.71$ & $40.21 \pm 3.31$ & $1.80 \pm 0.17$ & $165 \pm 12.4$ \\
$2 / 16 / 14$ & 480 & $229.32 \pm 24.86$ & $17.05 \pm 0.22$ & $1.24 \pm 0.36$ & $87.7 \pm 6.4$ \\
$2 / 16 / 14$ & 445 & $73.36 \pm 8.18$ & $6.19 \pm 0.85$ & $4.03 \pm 0.61$ & $7.22 \pm 5.8$ \\
$2 / 17 / 14$ & 485 & $57.96 \pm 6.44$ & $5.01 \pm 0.72$ & $0.63 \pm 0.18$ & $5.72 \pm 2.4$ \\
$2 / 17 / 14$ & 480 & $21.14 \pm 7.48$ & $1.93 \pm 0.23$ & $0.15 \pm 0.03$ & $6.03 \pm 3.2$ \\
$2 / 17 / 14$ & 470 & $37.12 \pm 5.32$ & $1.85 \pm 0.20$ & $0.090 \pm 0.014$ & $0.697 \pm 0.092$ \\
$2 / 18 / 14$ & 490 & $12.88 \pm 1.39$ & $0.70 \pm 0.08$ & $0.032 \pm 0.007$ & $3.42 \pm 1.02$ \\
$2 / 18 / 14$ & 465 & $9.29 \pm 1.00$ & $0.82 \pm 0.09$ & $0.039 \pm 0.006$ & $\mathrm{ND}$ \\
$2 / 18 / 14$ & 515 & $10.66 \pm 1.14$ & $0.95 \pm 0.11$ & $0.044 \pm 0.007$ & $\mathrm{ND}$ \\
$2 / 19 / 14$ & 463 & $4.62 \pm 0.50$ & $0.38 \pm 0.05$ & $0.018 \pm 0.004$ & $\mathrm{ND}$ \\
$2 / 19 / 14$ & 457 & $3.86 \pm 0.41$ & $0.36 \pm 0.04$ & $0.020 \pm 0.004$ & $\mathrm{ND}$ \\
$2 / 19 / 14$ & 490 & $4.32 \pm 0.46$ & $0.43 \pm 0.05$ & $0.016 \pm 0.004$ & $\mathrm{ND}$ \\
$2 / 20 / 14$ & 487 & $8.28 \pm 0.90$ & $0.72 \pm 0.08$ & $0.031 \pm 0.005$ & $\mathrm{ND}$ \\
$2 / 20 / 14$ & 487 & $3.34 \pm 0.37$ & $0.30 \pm 0.03$ & $0.013 \pm 0.003$ & $\mathrm{ND}$ \\
$2 / 20 / 14$ & 468 & $4.16 \pm 0.45$ & $0.43 \pm 0.05$ & $0.021 \pm 0.004$ & $\mathrm{ND}$ \\
\hline
\end{tabular}

$\mathrm{ND}=$ no detection 
Table 2. The ${ }^{241} \mathrm{Am},{ }^{239+240} \mathrm{Pu},{ }^{238} \mathrm{Pu}$ and ${ }^{241} \mathrm{Pu}$ concentrations (Bq) after HEPA filtration (Station B) following the February 14, radiation release event at the WIPP.

\begin{tabular}{cccccc}
\hline Sample Date & $\begin{array}{c}\text { Run time, } \\
\text { min }\end{array}$ & ${ }^{241} \mathrm{Am}, \mathrm{Bq}$ & ${ }^{239+240} \mathrm{Pu}, \mathrm{Bq}$ & ${ }^{238} \mathrm{Pu}, \mathrm{Bq}$ & ${ }^{241} \mathrm{Pu}, \mathrm{Bq}$ \\
\hline $2 / 14 / 14$ & 6300 & $842 \pm 102$ & $82.7 \pm 8.4$ & $11.9 \pm 3.2$ & $78.7 \pm 6.5$ \\
$2 / 18 / 14$ & 496 & $1.70 \pm 0.20$ & $0.15 \pm 0.02$ & $0.007 \pm 0.002$ & $10.2 \pm 3.4$ \\
$2 / 19 / 14$ & 469 & $0.93 \pm 0.11$ & $0.11 \pm 0.01$ & $0.005 \pm 0.002$ & $0.015 \pm 0.004$ \\
$2 / 19 / 14$ & 447 & $1.53 \pm 0.18$ & $0.20 \pm 0.03$ & $0.011 \pm 0.004$ & $4.89 \pm 0.20$ \\
$2 / 19 / 14$ & 488 & $1.45 \pm 0.17$ & $0.12 \pm 0.02$ & $0.006 \pm 0.002$ & $3.05 \pm 0.15$ \\
$2 / 20 / 14$ & 497 & $1.08 \pm 0.13$ & $0.10 \pm 0.01$ & $0.004 \pm 0.002$ & $2.22 \pm 0.17$ \\
$2 / 20 / 14$ & 482 & $1.95 \pm 0.22$ & $0.20 \pm 0.03$ & $0.007 \pm 0.002$ & $2.20 \pm 0.15$ \\
$02 / 20 / 14$ & 464 & $0.93 \pm 0.11$ & $0.08 \pm 0.01$ & $0.006 \pm 0.002$ & $0.46 \pm 0.04$ \\
$2 / 21 / 2014$ & 1416 & $3.26 \pm 0.09$ & $0.31 \pm 0.01$ & $0.014 \pm 0.003$ & $0.64 \pm 0.06$ \\
$2 / 22 / 2014$ & 1416 & $1.58 \pm 0.17$ & $0.15 \pm 0.02$ & $0.006 \pm 0.002$ & $\mathrm{ND}$ \\
$2 / 23 / 2014$ & 1459 & $1.04 \pm 0.11$ & $0.098 \pm 0.013$ & $0.004 \pm 0.002$ & ND \\
$2 / 24 / 2014$ & 1441 & $0.51 \pm 0.07$ & $0.054 \pm 0.008$ & $0.002 \pm 0.001$ & ND \\
$2 / 25 / 2014$ & 1434 & $0.30 \pm 0.03$ & $0.027 \pm 0.006$ & $0.005 \pm 0.002$ & ND \\
$2 / 26 / 2014$ & 1468 & $0.34 \pm 0.04$ & $0.037 \pm 0.006$ & $0.006 \pm 0.002$ & ND \\
$2 / 27 / 2014$ & 1507 & $0.30 \pm 0.03$ & $0.031 \pm 0.007$ & $0.007 \pm 0.003$ & ND \\
$2 / 28 / 2014$ & 1532 & $0.30 \pm 0.03$ & $0.029 \pm 0.004$ & $0.001 \pm 0.001$ & ND \\
$3 / 1 / 2014$ & 1381 & $0.37 \pm 0.04$ & $0.036 \pm 0.005$ & $0.002 \pm 0.001$ & ND \\
\hline
\end{tabular}

$\mathrm{ND}=$ No detection 
Table 3. Isotopic ratios of the radioactive materials released from the WIPP

\begin{tabular}{|c|c|c|c|c|c|}
\hline Sample type & $\begin{array}{l}{ }^{241} \mathrm{Am} /{ }^{239} \mathrm{Pu} \\
\text { Activity ratio }\end{array}$ & $\begin{array}{l}{ }^{241} \mathrm{Pu} /{ }^{239+240} \mathrm{Pu} \\
\text { Activity ratio }\end{array}$ & $\begin{array}{l}{ }^{238} \mathrm{Pu} /{ }^{239+240} \mathrm{Pu} \\
\text { Activity ratio }\end{array}$ & $\begin{array}{l}{ }^{240} \mathrm{Pu} /{ }^{239} \mathrm{Pu} \\
\text { Mass ratio }\end{array}$ & $\begin{array}{c}{ }^{241} \mathrm{Am} /{ }^{243} \mathrm{Am} \\
\text { mass ratio }\end{array}$ \\
\hline Breached drum & 4.75 & 3.42 & 0.045 & 0.073 & $479 \pm 90$ \\
\hline Panel 7, debris & $\begin{array}{c}5.24 \\
(4.68-5.95)\end{array}$ & - & - & 0.075 & $\begin{array}{c}455 \\
(411-501)\end{array}$ \\
\hline Panel 7,smears & $1.95-5.15$ & - & - & 0.078 & $467-472$ \\
\hline Panel 7 , swipes & $9.0-10.2$ & - & - & - & - \\
\hline $\begin{array}{l}\text { CAM filters } \\
(n=8)\end{array}$ & $12.1-22.2$ & - & - & $0.072-0.077$ & $461-523$ \\
\hline FAS 118 & 26.3 & - & - & - & - \\
\hline $\begin{array}{l}\text { Station A, } \\
\text { CEMRC data* }\end{array}$ & $4.81-20.67$ & $1.37-5.14$ & $0.03-1.0$ & - & - \\
\hline $\begin{array}{l}\text { Station B, } \\
\text { CEMRC data* }\end{array}$ & $2.95-19.72$ & $0.94-5.47$ & $0.028-0.214$ & - & - \\
\hline $\begin{array}{l}\text { Station A, } \\
\text { NWP data }\end{array}$ & 1.63 to 27.62 & - & $\begin{array}{c}0.048 \\
(0.003-0.080)\end{array}$ & - & - \\
\hline $\begin{array}{l}\text { Station B, } \\
\text { NWP data }\end{array}$ & 5.13 to 18.03 & - & $\begin{array}{c}0.050 \\
(0.003-0.273)\end{array}$ & - & - \\
\hline
\end{tabular}

*Activity ratio ${ }^{241} \mathrm{Am} /{ }^{239+240} \mathrm{Pu}$

${ }^{240} \mathrm{Pu} /{ }^{239} \mathrm{Pu}$ and ${ }^{241} \mathrm{Am} /{ }^{243} \mathrm{Am}$ mass ratio were taken from Technical Assessment Report-2015 


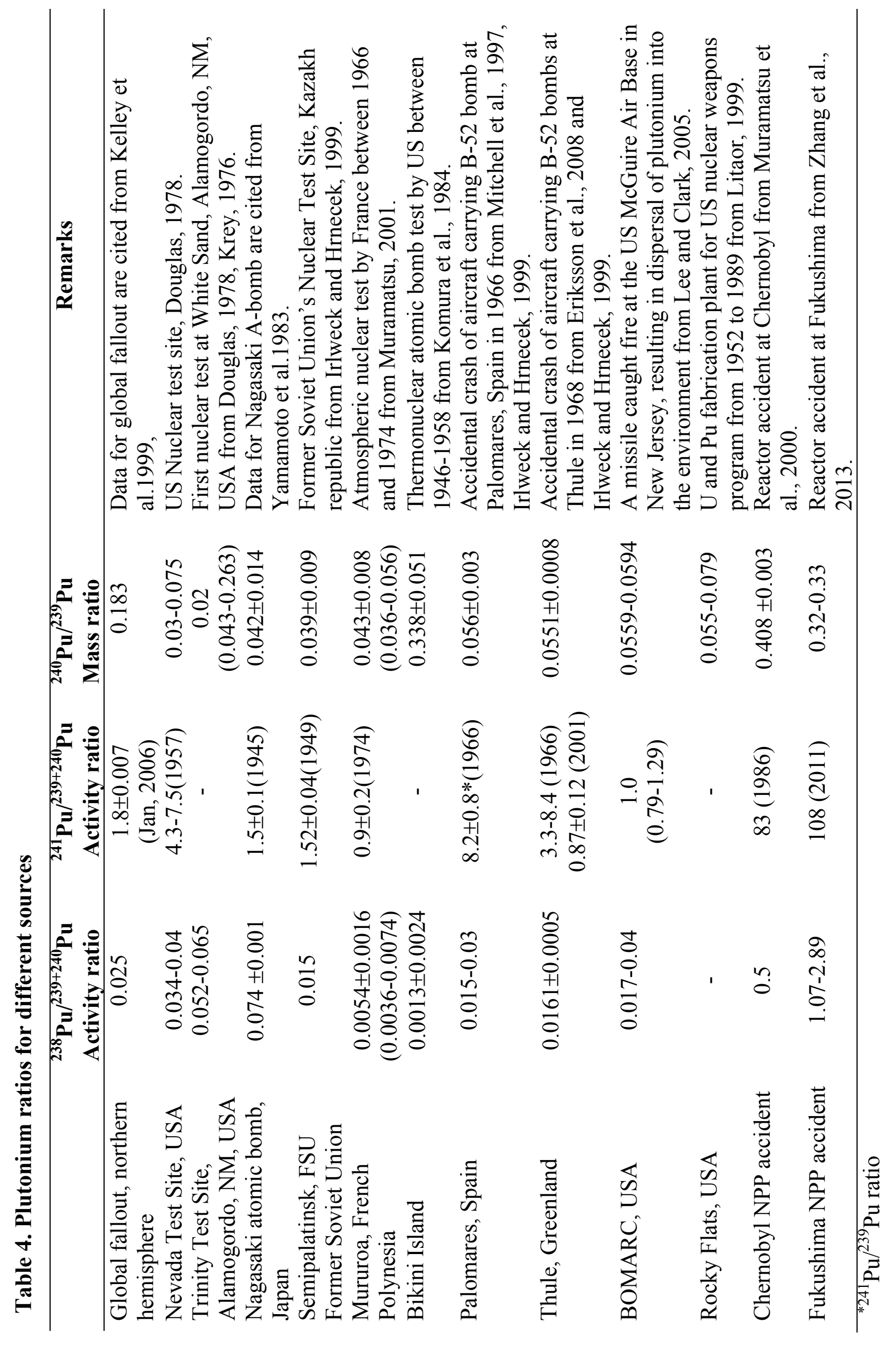

